\title{
The complexity of the concept of fragility in medical practice. Clinical implications of fragility syndrome in elderly patients associating cardiovascular diseases
}

\author{
Complexitatea conceputului de fragilitate în practica medicală. Implicaţiile clinice ale \\ sindromului de fragilitate la pacienţii vârstnici care asociază boli cardiovasculare
}

\author{
Oana Maria Stanciu' ${ }^{1}$, Cristian Teodorescu ${ }^{2}$, Sorin Riga ${ }^{1,3,4}$, Magdalena Budişteanu ${ }^{3}$, \\ Bogdan Budişteanu', Dan Riga ${ }^{1,3,4}$ \\ ${ }^{1}$ Universitatea de Medicină şi Farmacie „Carol Davila“, Bucureşti, România \\ ${ }^{2}$ Institutul Naţional de Neurologie şi Boli Neurovasculare, Bucureşti, România \\ ${ }^{3}$ Spitalul Clinic de Psihiatrie „Alexandu Obregia“, Bucureşti, România \\ ${ }^{4}$ Academia Oamenilor de Ştiinţă din România
}

\begin{abstract}
Frailty, in association with aging and chronic disorders, is a key predictive factor of the quality of life and ac-celerating aging, which contributes to disability and, therefore, has important social-economic implications. The frailty nosological specific features outline to elderly people must be emphasized with its correlative specificities. Without considering a gold standard, we consider that it is useful to make a few clear delimita-tions and correlations of various frailty concepts and of assessment methods and biomarkers that help easy identify fragile patients. Frailty is a result of the decreasing quality of life in the elderly, that could be prevent-ed, postponed or even improved by well-defined multi-factorial interventions.
\end{abstract}

Keywords: frailty, elderly, disability, cardiovascular diseases

\section{REZUMAT}

Fragilitatea, asociată cu îmbătrânirea şi afecţiunile cronice, este un principal factor predictiv al calităţii vieţii şi al îmbătrânirii accelerate, ceea ce contribuie la apariţia dizabilităţilor, cu implicaţii socio-economice importante. Conturarea particularităţilor nosologice ale fragilităţii la indivizii de vârsta a treia trebuie să pună accentul pe specificităţile corelative ale acesteia. Fără să existe un standard de aur, considerăm că este util să facem câte-va delimitări clare şi corelaţii ale diverselor concepte de fragilitate şi ale unor metode de evaluare şi biomakeri, care să contribuie la identificarea cu uşurinţă a pacienţilor fragili. Fragilitatea reprezintă o condiţie a scăderii calităţii vieţii vârstnicului, care ar putea fi prevenită, amânată, ameliorată sau chiar recuperată prin intervenţii multifactoriale bine conturate.

Cuvinte cheie: fragilitate, vârstnici, dizabilitate, afecţiuni cardiovasculare

\section{INTRODUCERE}

Îmbătrânirea este asociată cu prezenţa fragilităţii şi a afecţiunilor cronice, ceea ce determină apariţia unui declin funcţional şi cognitiv, precum şi scăderea autonomiei şi apariţia dizabilităţii. Fragilitatea este cel mai întâlnit sindrom în rândul populaţiei vârstnice şi este asociată cu un declin al rezer- velor structurale şi fiziologice, precum şi perturbări ale homeostaziei organismului.

În ultimul deceniu, conceptul de fragilitate este tot mai studiat şi utilizat în abordarea pacientului vârstnic care asociază afecţiuni cardiovasculare. Creşterea speranţei de viaţă în ţările dezvoltate şi utilizarea în practica medicală a celor mai noi metode de diagnostic şi tratament ale afecţiunilor car- 
diace au determinat înregistrarea unui număr tot mai mare de pacienţi cu vârsta de peste 65 de ani cu sănătate relativă. Majoritatea studiilor clinice care includ pacienţi vârstnici nu evaluează calitativ şi cantitativ statusul de fragilitate şi astfel există puţine date clinice care oferă informaţii cu privire la această categorie de pacienţi.

Disproporţionalitatea dintre natalitate şi mortalitate din întreaga lume determină accelerarea îmbătrânirii populației şi, implicit, creșterea numărului de persoane vârstnice. Astfel, până în 2050, populaţia vârstnică va depăşi numărul populaţiei adolescente cu vârsta de 10-14 ani (1). Datele statistice europene arată că segmentul de populaţie cu vârsta de peste 65 de ani prezintă fragilitate într-un procent de $6-27 \%$. În privinţa persoanelor considerate prefragile, cu vârsta de peste 54 de ani, prevalenţa creşte semnificativ cu $35 \%$ până la $51 \%$ (2).

\section{CONCEPTUL DE FRAGILITATE ÎN STUDIUL ÎMBĂTRÂNIRII}

Îmbătrânirea constă în fragilizarea tuturor sistemelor şi aparatelor organismului, favorizând apariţia polipatologiei. Vulnerabilitatea (v.) vârstnicului (factor cheie în biomedicină), cu cele două laturi ale sale (v. biologică şi v. neuropsihică) se reflectă prin ansamblul factorilor moşteniţi sau dobândiţi care predispun la apariţia şi dezvoltarea bolilor (3).

Cele două mecanisme etiopatogenice comune în îmbătrânirea patologică sunt: inflamm-aging şi desfăşurarea ontogenetică entropică reprezentată de tetrada dezorga-nizatoare: stres, uzură, îmbătrânire şi polipatologie. Fiecare proces acţionează asupra următorului prin creşterea vulnerabilităţii şi scăderea adaptabilităţii, determinând îmbătrânirea patologică şi accelerarea ei (4).

Conceptul de fragilitatea în studiul îmbătrânirii cuprinde trei procese-direcţii care au drept efect apariţia unui status patogenic:

- Scăderea adaptabilităţii organismului;

- Creşterea fragilizării multiplelor sisteme de organ;

- Apariţia comorbidităţilor care îşi cresc reciproc severitatea.

În prezent, mecanismul etio-patogenic al fragilităţii nu este clar stabilit. Modificările ce au loc la nivel molecular şi celular în contextul îmbătrânirii prezintă un interes tot mai mare, iar rezultatele unor studii sugerează inflamaţia cronică şi activarea sistemului imunitar ca fiind un posibil mecanism (5). Astfel, imunitatea celulară şi modificările care au loc odată cu îmbătrânirea contribuie la apariţia imunosenescenţei (6). Precursorii celulelor timice migrează din zona cortexului în zona medulară a timusului, unde are loc procesul de maturare pentru a deveni limfocite CD4+ ( celule T helper, implicate în imunitatea umorală şi liza microbiană intracelulară) sau CD8+ (celule citotoxice T) (7). Prin urmare, diferitele componente ale răspunsului imun nu sunt afectate de îmbătrânire în acelaşi mod. Acest lucru generează un dezechilibru între citokine proinflamatorii şi antiinflamatorii, în favoarea aparţiei unei stări inflamatorii cronice (8).

\section{DEFINIȚIA FRAGILITĂṬII}

Conceptul de fragilitate a atras interesul specialiştilor, fiind tot mai utilizat în cercetarea ştiinţifică şi practica medicală. În absenţa unei definiţii precise şi universal acceptate a fragilităţii, există două abordări cel mai frecvent utilizate: fragilitatea ca sindrom vs. fragilitatea ca entitate.

Fenotipul de fragilitate, descris pentru prima oară de către Fried şi colaboratorii (2001) (9), este definit ca fiind un sindrom clinic dominat de existenţa a cel puţin 3 dintre cele 5 criterii fenotipice: slăbiciune, epuizare autoraportată, activitate fizică redusă, pierderea în greutate neintenţionată (4-5 kilograme în ultimul an), reducerea vitezei de mers. Prezenţa a cel mult două criterii defineşte forma subclinică - prefragil, care are un risc crescut pentru fragilitate (9).

Rockwood şi colaboratorii propun în 2007 un nou mod de abordare a fragilităţii. Indicele de fragilitate defineşte fragilitatea prin prezenţa unui număr mare de deficite de organ stabilite printr-o evaluare geriatrică cuprinzătoare. Autorul propune evaluarea indexului de fragilitate cu ajutorul unui chestionar complex ce conţine 70 de elemente care evaluează deficitele fără a face o distincţie între fragilitate şi dizabilitate sau comorbidităţi (10).

\section{DECLINUL FUNCȚIONAL ŞI FRAGILITATEA}

Fragilitatea frecvent întâlnită la persoanele cu vârsta peste 60 de ani este asociată cu un declin al rezervelor fiziologice şi perturbări ale homeostaziei organismului (11). Lipsa unei definiţii precise a fragilităţii ridică dificultăţi în stabilirea componentelor acesteia. În consecinţă, unii autori au inclus dizabilitatea şi declinul funcţional ca fiind componente ale fragilităţii, iar alţi autori consideră dizabilitatea şi declinul funcţional o consecinţă a fragilităţii $(12,13,14)$. Activitatea fizică regulată contribuie la prevenirea apariţiei diferitelor componente ale fragilităţii cum ar fi sarcopenia, diminua- 
rea statusului funcţional şi cognitiv din cauza implicaţiilor în menţinerea capacităţii funcţionale, a greutăţii corporale normale şi a masei musculare.

Declinul funcţional este cel mai frecvent sindrom clinic ce determină reducerea mobilităţii şi pierderea independenţei vârstnicului (15). Acesta se manifestă prin apariţia unor simptome non-specifice, evoluţie insidioasă şi progresivă asociată cu manifestări multiple. Pierderea progresivă şi generalizată a masei musculare scheletice şi, implicit, a forţei musculare din cauza sarcopeniei determină pierderea independenţei, dizabilitate şi scăderea calităţii vieţii (16).

În mecanismul de apariţie a sarcopeniei are loc înlocuirea fibrelor musculare striate cu celule grăsoase şi creşterea fibrozei în miocite. În cazul vârstnicilor, trebuie făcută distincţia între sarcopenia primară, cauzată de vârstă, şi sarcopenia secundară - asociată cu afecţiuni sau tratamente ce implică scăderea masei musculare.

Nutriţia vârstnicului reprezintă un factor deosebit de important şi care este corelat cu starea de sănătate. Malnutriţia favorizează apariţia sarcopeniei şi, implicit, a fragilităţii (17). Declinul rapid al indicelui de masă corporală la vârstnici este un factor predictiv al deteriorării funcţionalităţii prin pierderea autonomiei, apariţia unei boli coronariene şi, implicit, un prognostic nefavorabil.

\section{AFECTIIUNILE CARDIOVASCULARE SPECIFICE VÂRSTEI A TREIA ŞI FRAGILITATEA}

Bolile cardiovasculare (BCV) sunt cunoscute ca fiind principala cauză de dizabilitate, spitalizare şi costuri ridicate la nivel mondial (18). Potrivit Organizaţiei Mondiale a Sănătăţii, boala coronariană şi accidentul vascular cerebral contribuie la creşterea mortalităţii la nivel mondial în rândul populaţiei vârstnice.

Sindromul de fragilitate manifestă o serie de semne şi simptome care interferă cu polipatologia existentă. Disfuncţiile endocrine şi nivelul crescut al markerilor inflamatori au fost identificate în rândul indivizilor fragili care asociază boli cardiovasculare (19). Astfel, bolile cardiovasculare pot agrava gradul de sarcopenie şi favoriza apariţia fragilităţii în timp ce prezenţa fragilităţii creşte gradul de morbiditate şi mortalitate a bolilor cardiovasculare (20).

Fiziopatologia fragilităţii, asociată cu boli cardiovasculare, implică prezenţa unui proces de inflamaţie cronică, ca urmare a unei disfuncţii metabo- lice, creşterea stresului oxidativ şi a procesului catabolic (21). Ateroscleroza este influenţată de prezenţa sarcopeniei şi a fragilităţii. Prin urmare, asocierea dintre ateroscleroza carotidiană, rigiditatea arterială şi sarcopenie contribuie la agravarea aterosclerozei şi apariţia fragilităţii (22).

În prezent, relaţia dintre fragilitate şi bolile cardiovasculare a fost intens studiată. Compendiul de ghiduri elaborat de Societatea Europeană de Cardiologie conţine recomandări ale managementului afecţiunilor vasculare în cazul unor situaţii specifice - pacienţii vârstnici şi fragili. $\mathrm{Cu}$ toate acestea, datele clinice care să furnizeze informaţii precise cu privire la tratamentul medical optimizat la această categorie de pacienţi sunt limitate. În cazul pacienţilor cu vârsta de peste 90 de ani, cu multiple comorbidităţi şi cu o stare funcţională limitată, se recomandă evaluarea raportului de risc/beneficii în managementul afecţiunii cardiovasculare şi, nu în ultimul rând, trebuie avută în vedere decizia finală a pacientului cu privire la intervenţiile medicale personalizate.

Programele de prevenţie cardiovasculară reprezintă cel mai important mijloc de combatere a suferinţei vârstnicului din cauza bolilor cardiovasculare (23). Obiectivele principale ale prevenţiei BCV sunt: reducerea incidenţei primului eveniment clinic cardiovascular şi a recurenţelor ca urmare a bolii coronariene, a accidentului vascular cerebral ischemic sau a bolii arteriale periferice, prevenirea dizabilităţii cauzată de un eveniment cardiovascular acut (24). Scopul final constă în creşterea ratei de supravieţuire şi a calităţii vieţii. Îngrijirea pacienţilor vârstnici şi fragili devine dificilă din cauza polipatologiei complexe şi a vulnerabilităţii induse de un grad mare de deteriorare.

\section{METODE ŞI SCALE DE EVALUARE A FRAGILITĂṬII}

Identificarea fragilităţii poate determina aprecierea riscului de scădere a autonomiei, căderi, spitalizare, instituţionalizare şi deces în rândul persoanelor cu vârsta peste 65 de ani (25). Identificarea sindromului de fragilitate, evaluarea statusului funcţional şi corectarea factorilor de risc cardiovasculari contribuie la:

- stabilirea persoanelor prefragile sau cu risc crescut de a deveni fragili;

- Intervenţii prin metode specifice, care să menţină gradul de independenţă şi să îmbunătăţească calitatea vieţii pacienţilor geriatrici. 
Pentru screening-ul sindromului de fragilitate în practica medicală zilnică au fost propuse numeroase definiții operaţionale în evaluarea statusului de fragilitate, dar niciuna dintre acestea nu a fost validată până în prezent în România. De asemenea, nu există niciun instrument de screening general acceptat la nivel european.

Evaluarea geriatrică cuprinzătoare (Comprehensive Geriatric Assessement - CGA) este considerată „standardul de aur" pentru evaluarea şi managementul fragilităţii (26). Reprezintă un model de evaluare globală multidisciplinară atât a problemelor de sănătate fizice şi psihice, cât şi a statusului funcţional şi social al persoanelor vârstnice (27). $\mathrm{Cu}$ toate acestea, nu întotdeauna este posibilă efectuarea integrală a CGA.

Fenotipul de fragilitate evaluează fragilitatea pe 5 dimenisiuni: pierderea în greutate, oboseala, scăderea forţei, lentoarea şi nivelul scăzut de activitate (9). Această abordare a evaluării fragilităţii geriatrice indică scăderea capacităţii de adaptare a organismului odată cu îmbătrânirea, capacitate esenţială pentru starea de sănătatea şi menţinerea gradului de independenţă a vârstnicului.

Numeroase ţări europene au adoptat un chestionar la nivel naţional, de evaluare a fragilităţii, adaptat la acest segment de populaţie. În Franţa, Spitalul Universitar din Toulouse - Gérontopôle a elaborat un chestionar utilizat în reţeaua de asistenţă medicală primară care identifică pacienţii fragili. Chestionarul întocmit de Gérontopôle corespunde criteriilor lui Fried, iar itemii utilizaţi în chestionar iau în considerare atât statusul cognitiv, cât şi statusul social (28). Societatea de Geriatrie Britanică propune pentru identificarea pacienţilor fragili utilizarea chestionarului Prisma 7 (29).

Indicele de Fragilitate Groningen (Groningen Frailty Index - GFI) reprezintă un chestionar valid, utilizat în asistenţa primară, ce identifică vârstnicii fragili sau prefragili şi care constă în 15 întrebări pe care trebuie să le completeze pacientul. Chestionarul GFI este structurat pe 3 sub-scale care evaluează: activităţi zilnice, funcţia psihosocială şi probleme de sănătate (30). Acesta a fost utilizat în România într-un studiu efectuat la nivelul asistenţei medicale primare - la nivelul cabinetelor de medicină de familie, dar şi în clinici universitare de geriatrie (31).

În domeniul cardiologiei, principalul instrument de evaluare a fragilităţii utilizat în studiile clinice este testul vitezei de mers. Acest test reprezintă un instrument predictiv independent cu decesul, spitalizarea pacienţilor cu insuficienţă cardiacă sau alte cauze de spitalizare (32). Este recomandată inclu- derea testului în evalaurea clinică a pacienţilor vârstnici, care asociază comorbidităţi cardiovasculare. De asemenea, îmbunătăţeşte stratificarea riscului la pacienţii geriatrici cu insuficienţă cardiacă evaluată cu ajutorul scorului 3C-HF (Cardiac and Comorbid Conditions Heart Failure score).

Scala clinică de fragilitate reprezintă un instrument practic şi eficient în evaluarea fragilităţii, la admiterea în serviciile medicale de urgenţă, în special în cazul intervenţiilor chirurgicale cardiace (33).

\section{POTENȚIALI BIOMARKERI UTILIZAȚI ÎN IDENTIFICAREA FRAGILITĂȚII}

În prezent, nu a fost dezvoltat niciun model standard de biomarkeri care să contribuie la identificarea fragilităţii. Numeroase studii publicate în literatura de specialitate au identificat o serie de potenţiali biomarkeri care ar putea contribui la evaluarea şi diagnosticul fragilităţii. Testele de laborator sunt utilizate în cercetarea ştiinţifică.

Fragilitatea şi bolile cardiovasculare au o componentă inflamatorie comună (34). Inflamaţia cronică, mecanismul comun în ateroscleroză şi fragilitate, a fost identificat cu ajutorul a patru markeri inflamatori comuni: interleukina-6, proteina $\mathrm{C}$ reactivă, fibrinogenul şi D-dimeri (35). Deoarece markerii inflamatori nu sunt utilizaţi în mod obişnuit în evaluarea clinică, alţi markeri precum hemoglobina au fost studiaţi pentru diagnosticul clinic de fragilitate.

Deficitul concentraţiei de hemoglobină a fost asociat cu creşterea gradului de dependenţă din cauza limitării activităţilor zilnice (36). O concentraţie scăzută de 25-hidroxivitamină-D (25-OHD) a fost asociată cu o încetinire a vitezei de mers şi tulburări de echilibru (37).

\section{CONCLUZII}

Pentru a stabili fragilitatea ca entitate clinică, este necesară includerea factorilor biologici. Principalele procese implicate în apariţia fragilităţii sunt: sistemul imunitar şi prezenţa inflamaţiei cronice, asociate cu sarcopenia - principala componentă a fragilităţii.

Stabilirea interrelaţiilor între fragilitate şi prezenţa bolilor cardiovasculare, a mecanismelor etiopatogenice şi metabolice comune poate conduce la eficientizarea şi optimizarea tratamentului profilactic, curativ şi de recuperare. Este necesară conştientizarea acestui concept multidimensional în rândul 
clinicienilor şi al populaţiei aflate la risc, cu o atitudine de prevenire şi tratament nonfarmacologic. Rezultatele obţinute vor contribui la scăderea efec-

\section{BIBLIOGRAFIE}

1. United Nations, Department of Economic and Social Affairs, Population Division. World Population Ageing. New York: Published by the United Nations, 2015:24-25.

2. Santos-Eggiman B, Cuenoud P, Spagnoli J et al. Prevalence of frailty in middle-aged and older community-dwelling europeans living in 10 countries. J Gerontol A Biol Sci Med Sci. 2009;64A:675-681.

3. Stanciu OM, Teodorescu C, Riga S, Riga D. Fragilitatea vârstnicului, comorbidităţi, polipatologie şi boala Alzheimer, Conferința Natională Alzheimer 2015 cu participare Internațională, 2015.

4. Riga D, Riga S. Medicina Anti-Îmbătrânire şi Ştiinţele Longevităţii. Bucureşti: Editura Cartea Universitară, 2007:99-118.

5. Darvin K, Randolph A, Ovalles S et al. Plasma protein biomarkers of the geriatric syndrome of frailty. Gerontol. A Biol. Sci. Med. Sci. 2014;69:182-186.

6. Zierer J, Menni C, Kastenmüller G et al. Integration of 'omics' Data in Aging Research: from Biomarkers to Systems Biology. Aging Cell. 2015;14(6):933-944.

7. Palmer B. The effect of age on thymic function. Front Immunol.2013;4:316

8. Rea IM, Gibson DS, Mc Gilligan V. Age and age related diseases: role of inflammation triggers and cytokines. Front Immunol.2018;9:586

9. Fried LP, Tangen CM, Walston J et al. Frailty in Older Adults: Evidence for a Phenotype. J Gerontol A Biol Sci Med Sci. 2001;56:M146-M156.

10. Rockwood K, Stadnyk K, MacKnight $C$ et al. A brief clinical instrument to classify frailty in elderly people. Lancet. 1999;353:205-206.

11. Lang PO, Michel JP, Zekry D. Frailty syndrome: a transitional state in a dynamic process. Gerontology. 2009;55(4):539-49.

12. Ruikes F, Zuidema S, Akkermans $R$ et al. Multicomponent program to reduce functional decline in frail elderly people: a cluster controlles trial. J Am Board Fam Med. 2016;29(2):209-217.

13. Rockwood K, Mitnitski A. Frailty in relation to the accumulation of deficits. J Gerontol A Biol Sci Med Sci. 2007; 62(7):722-7.

14. Sternberg SA, Schwartz AW, Karunananthan S et al. The identification of frailty: a systematic literature review. J Am Geriatr Soc. 2011;59(11):2129-2138.

15. Bock J, König $\mathrm{H}$, Brenner $\mathrm{H}$ et al. Associations of frailty with health care costs - results of the ESTHER cohort study. BMC Health Serv Res. 2016;16:128.

16. Cruz-Jentoft AJ, Baeyens JP, Bauer JM et al. Sarcopenia: European consensus on definition and diagnosis: Report of the European Working Group on Sarcopenia in Older People. Age Ageing. 2010;39(4):412-23.

17. Morley JE, von Haehling S, Anker SD, Vellas B. From sarcopenia to frailty: a road less traveled. $J$ Cachexia Sarcopenia Muscle. 2014; 5:5-8.

18. Afilalo J. Frailty in patients with cardiovascular disease: Why, when, and how to measure. Curr Cardiovasc Risk Rep. 2011;5:467-72.

19. Velissaris D, Pantzaris N, Koniari I et al. C-reactive protein and Frailty in the elderly: a literature review. J Clin Med Res. 2017;9(6):461-465.

20. Go AS, Mozaffarian D, Roger VL et al. Heart disease and stroke statistics-2013 update: A report from the American Heart Association. Circulation. 2014;129(3):e28-e292. telor negative, a costurilor şi la dezvoltarea unui nou model de îngrijire medicală, precum şi la creşterea calităţii vieţii.

21. Hongyu L, Sun K, Zhao R et al. Inflamatory biomarkers of coronary disease. Front Biosci. 2018;10:185-196.

22. Chainani V, Riehl R, Chainani G, Abdo A, Cohen M, Alfonso C, Clark P, Lavie C, Reilly J, Rafeh N. Frailty and cardiovascular disease. In Yannis Dionyssiots (ed.) Frailty and sarcopenia - onset, development and clinical challenges ed. Intech, 2017:197-220.

23. Afilalo J, Karunananthan S, Eisenberg MJ et al. Role of frailty in patients with cardiovascular disease. Am J Cardiol. 2009;103(11):1616-21.

24. Dumurgier J, Elbaz A, Ducimetière $P$ et al. Slow walking speed and cardiovascular death in well functioning older adults: Prospective cohort study. BMJ. 2009;339:B4460.

25. Abellan van Kan G, Rolland Y, Bergman H, Morley JE, Kritchevsky SB, Vellas B. The I.A.N.A. Task Force on frailty assessment of older people in clinical practice. J Nutr Health Aging. 2008;12(1):29-37.

26. Pritchard JM, Kennedy CC, Karampatos $S$ et al. Measuring frailty in clinical practice: a comparison of physical frailty assessment methods in a geriatric out-patient clinic. BMC Geriatr. 2017;17:264.

27. Parker sg, Mc Cue P, Phelps K et al. What is Comprehensive Geriatric Assessment (CGA)? An umbrella review. Age Ageing. 2018;47(1):149155.

28. Cherubini A, Demougeot $L$, Jentoft A et al. Validation of the Gérontopôle frailty screening tool to detect frailty in primary care. J Frailty Aging. 2013;150-152.

29. British Geriatrics Society. Fit for Frailty - Consensus best practice guidance for the care of older people living with frailty in community and outpatient settings. London, 2014:9-14.

30. Drubbe I, Bleijenberg N, Kranenburg $G$ et al. Identifying frailty: do the Frailty Index and Groningen Frailty Indicator cover different clinical perspectives? BMC Family Practice. 2013;14:64.

31. Stanciu OM, Mateescu R, Aurelian S et al. Early detection of Alzheimer disease and Groningen frailty index. Oral Poster presentation - National Alzheimer Conference. Bucharest, 2015.

32. Matsuzawa Y, Konishi M, Akiyama E et al. Association between gait speed as a measure of frailty and risk of cardiovascular events after myocardial infarction. J Am Coll Cardiol. 2013;61:1964-72.

33. Newman AB, Gottdiener JS, McBurnie MA et al. Associations of subclinical cardiovascular disease with frailty. J Gerontol A Biol Sci Med Sci. 2001;56:M158-66.

34. Teodorescu C, Stanciu OM, Riga S, Riga D. Inflammation - c common key mechanism in frailty syndrome and Alzheimer disease. Oral Poster presentation - National Alzheimer Conference. Bucharest, 2015.

35. Lara J, Cooper R, Nissan J et al. A proposed panel of biomarkers of healthy Ageing. BMC Med. 2015;13(1):222.

36. Khandelwal D, Goel A, Gulati V et al. Frailty is associated with longer hospital stay and increased mortality in hospitalized older patients. $J$ Nutr Health Aging. 2012;16(8):732-735.

37. Mitnitski A, Collerton J, Ruiz C et al. Age-related frailty and its association with biological markers of ageing. BMC Medicine. 2015;13:161. 